\title{
MICROSOFT OFFICE 365 ON LEARNING HISTORY SUBJECT
}

\author{
Jamiludin $^{1)}$, Darnawati ${ }^{2)}$, Sukadi Linta ${ }^{3)}$, Anugrah Puspita Ayu Muhammad ${ }^{4)}$, Waode Ade Sarasmita Uke ${ }^{5)}$ \\ 1) University of Halu Oleo, Indonesia \\ E-mail: jamiluddin@uho.ac.id \\ 2) University of Halu Oleo, Indonesia \\ E-mail:darnawati@uho.ac.id \\ 3) Senior High School State 4 Kendari, Indonesia \\ E-mail: ditasman4kendari@gmail.com \\ 4) University of Halu Oleo, Indonesia \\ E-mail: anugrah.p.ayu@uho.ac.id \\ 5) University of Halu Oleo, Indonesia \\ E-mail: wd.ade_sarasmitauke@uho.ac.id
}

\begin{abstract}
This research aimed at knowing the students' perception of Microsoft Office 365 on learning history. This research used a quantitative descriptive design. It was conducted at SMAN 4 Kendari, Southeast Sulawesi. The sample of this study was students in XI-1 grade. The students were 46. Research instruments used questionnaires and interviews. The result showed that the students had a positive response toward the use of Microsoft Office 365 . Besides, $87 \%$ of students agree that they can understand History Subject during online learning. The most frequently used features were Teams (95.7\%), SharePoint (2.2\%), and Forms (2.2\%). T However, the obstacle of using this application is if students do not have facilities such as a good internet network, and laptops.
\end{abstract}

Keywords: Students’ Perception; Microsoft Office 365; Learning History

\section{INTRODUCTION}

The effectiveness of History Subject that takes place in schools today needs to be considered. History Subject which is usually carried out face-to-face is still often complained of and not paid attention to by students. They think that History Subject is not important and irrelevant (Van Straaten, Wilschut, \& Oostdam, 2016). Unlike today, History Subject is done through online learning during the COVID-19 pandemic. In the face of reduced communal activities, online learning is the most practical alternative (Sanoto, 2021); and (Chang \& Aytenew, 2021). Therefore, the effectiveness of History Subject is highly dependent on the teacher's teaching strategies, History Subject models, history materials and textbooks, and the professionalism of history teachers. It is in line with Rijal Fadli, Sudrajat, Setiawan, \& Amboro (2020) stated that learning models that influence the learning process, one of the most important factors in learning success is the usage of learning resources and media during the learning process.

In general, teachers are not aware of their role and are not professional in fostering History Subject, this can be seen from the frequent learning in schools that gets the spotlight because it turns out that History Subject is held inappropriately. Conventional History Subject methods or strategies are often the problems raised. The lack of teacher ability in mastering technology in learning (Efriana, 2021), lack of references, and rarely attending workshops or training on learning applications is also some of the obstacles for teachers to be less creative in managing classes. The impact of History Subject causes students to often skip class during class hours, students are noisy in class, and often sleepy so that history subjects are less noticed by students.

Based on initial observations with the school at SMAN 4 Kendari, teachers at the school use Microsoft Office 365 applications during online learning. Likewise history subjects, history teachers are required to master the use of the application. The lecture method is usually used when learning history offline, but when learning online, teachers are required to be able to take advantage of technology by using the help of Microsoft Office 365 applications and WhatsApp . Besides, based on information and interviews obtained from students, especially class XI students, most students think that history subjects are less interesting because the material provided is in the form of memorizing events, important figures, and 
years. This makes students less motivated to understand the material in history subjects (Umasih, 2018).

The use of Microsoft Office 365 applications in History Subject is one way that can be used by teachers to increase the effectiveness of online learning. This application provides various facilities for teachers and students in the learning and teaching process, as well as training students' mastery in using multimedia, especially in the field of history, inseparable from the use of Microsoft office in its application. The provision of materials, assignments, and communication between teachers and students can be done using the Microsoft Office 365 application (Ardian, 2020). This History Subject innovation is expected to increase students' motivation in learning history.

Research using Microsoft Office 365 applications has previously been used by several researchers, including Aziizah, Sakti, \& Andriyanto, (2020); Ardian (2020); and Situmorang (2020). Based on this research, shows that Microsoft Office 365 applications have a positive impact on online learning. Teachers use it not only for sending assignments and materials but also for video conferences. Looking at the results of previous studies, this research aims at knowing the students' response to Microsoft Office 365 applications in learning history at SMAN 4 Kendari.

\section{METHODS}

The design used in this research was quantitative descriptive. This research was conducted at SMAN 4 Kendari, Southeast Sulawesi. The sample of this study was students in XI-1 grade. The students were 46. For selecting the sampling, the researcher used purposive sampling. XI-2 grade was used to pilot the instruments.

Research instruments used questionnaires and interviews. The interview had five questions for the students. The questionnaire, containing seven statements. The questionnaire was about the students' perception of the use of Microsoft Office 365 in learning history. In measuring the data, the students were asked to indicate their agreement or disagreement with each statement on a 4-point Likert scale that ranged from strongly disagree, score 1 , to strongly agree, score 4.

Before using the questionnaire, the researchers distributed the questionnaire to the pilot class. To know the validity and reliability of the instruments. The results to be obtained first are the results of the validity and reliability test of the questionnaire. The result of the validity of the test is as follows:

TABLE 1

The Result of the Validity Test

\begin{tabular}{lllllll}
\hline \multicolumn{7}{c}{ Pearson Correlation } \\
Q1 & $\mathbf{Q 2}$ & $\mathbf{Q 3}$ & $\mathbf{Q 4}$ & $\mathbf{Q 5}$ & $\mathbf{Q 6}$ & $\mathbf{Q 7}$ \\
\hline .871 & .720 & .850 & .776 & .908 & .681 & .688 \\
\hline
\end{tabular}

The table above shows that the value of $r$ count $>r$ table (0.3044) was based on a significant test of 0.05 . It showed the items above were valid.
TABLE 2

The Result of the Reliability Test

\begin{tabular}{cc}
\hline \multicolumn{2}{c}{ Reliability Statistics } \\
\hline Cronbach's Alpha & N of Items \\
.888 & 7 \\
\hline
\end{tabular}

The result showed that the overall Cronbach Alpha Coefficient of the questionnaire is $(r=0.888)$, indicating a high degree of internal consistency. Thus, it is considered a reliable instrument.

To examine the questionnaire's validity, the Product Moment Test, while reliability, was tested using Cronbach's Alpha Test. The researcher used descriptive statistics for computing the questionnaire analysis using SPSS (Statistical Package for the Social Sciences) 25 Program.

The procedures of data collection in this research namely: (1) preparing research instruments such as questionnaires and guideline interviews for students. ((2) The questionnaire's validity and reliability were tested by the researcher. (3) Using Google Forms, ask the students to complete the questionnaires for a week. They had a personal interview over WhatsApp as well. (4) The researcher analyzed the data.

\section{RESULT AND DISCUSSION}

The data were taken from the questionnaire that was given to the XI-1 Grade students. The subject of this study was the XI-1 Grade students who were taught by using Microsoft Office 365 on History subjects. The following charts describe the research result.

\section{What features in Microsoft Office 365 do you use most in History Subject?}

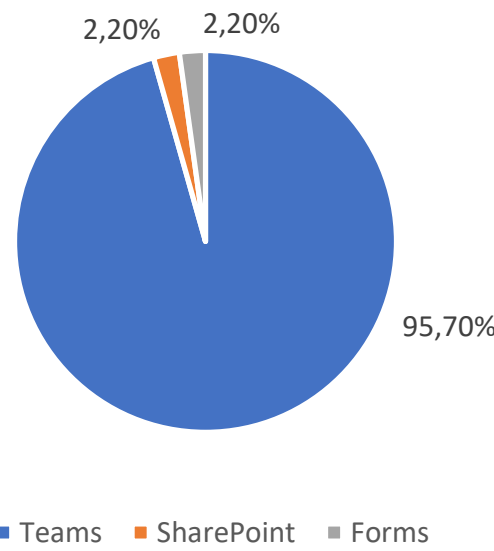

Fig. 1. The Most Used Features of Microsoft Office 365 on Learning History

Based on Figure 1, the students use some features of Microsoft Office 365 on learning History subjects. The figure shows that they use Teams $(95.7 \%)$, SharePoint $(2.2 \%)$, and Forms (2.2\%). This result is in line with Situmorang (2020) showed that students' interest in learning through Microsoft Teams was very good. The result of the interview also showed 
that they like to use it because it has some features that help them during conducting online learning, such as video conferencing (Widiyarso \& Sutama, 2021). Because Microsoft Teams is backed by features that promote the implementation of online learning, using it seeks to maximize the deployment of online learning (Wirza \& Ofionto, 2021). Besides, the students also said it can help to understand History Subject. One of the advantages of Microsoft Teams is the quality of the video and HD is good (Nafisah \& Fitrayati, 2021).

Moreover, Microsoft forms and share points were rarely used. Microsoft forms are usually used to fill the attendance list. While share point was rarely used.

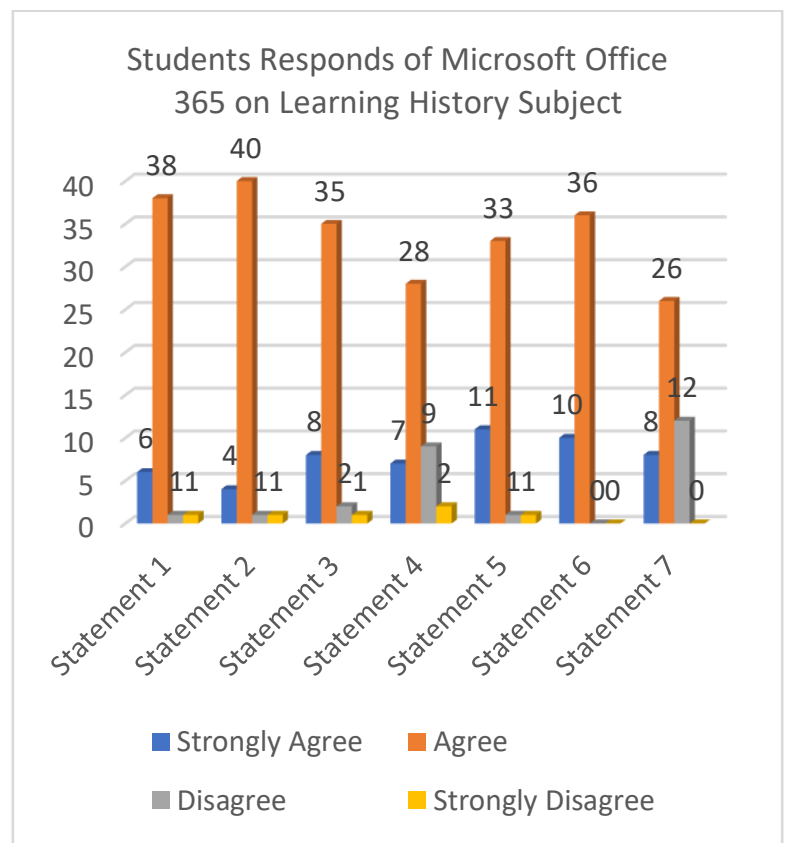

Fig. 2. Students Responds to Microsoft Office 365 on Learning History Subject

Figure 2 shows the students' responses to Microsoft Office 365 on Learning History Subject. Based on the figure above, it shows that on Statement 1, there are 6 students (13\%) who strongly agree that Microsoft Office 365 is very fun to be used on learning History subjects. There are 38 students $(82.6 \%)$ who agree, however, there is 1 student each who disagrees and strongly disagrees that Microsoft Office 365 is very fun to be used on learning History subjects. On Statement 2, there are 4 students $(8.7 \%)$ who strongly agree that Microsoft Office 365 can help them to improve their knowledge of History, 40 students $(87 \%)$ who agree, and 1 student each who disagrees and strongly disagrees. On Statement 3, there are 8 students (17.4) who strongly agree that Microsoft Office 365 is practical for use in online History Subject activities during the Covid-19 pandemic, 35 students $(76.1 \%)$ who agree, 2 students $(4.3 \%)$ who disagree, and 1 student (2.2\%) who strongly disagrees.

On Statement 4, there are 7 students (15.2\%) who strongly agree that Microsoft Office 365 is very economical and affordable in internet consumption for use during the online learning process, 28 students $(60.9 \%)$ who agree, 9 students $(19.6 \%)$ who disagree, and 2 students $(4.3 \%)$ who strongly disagree. On Statement 5, there are 11 students (23.9\%) who strongly agree that Microsoft Office 365 is very easy to use during the online History Subject process, 33 students $(71.7 \%)$ who agree, and 1 student each who disagrees and strongly disagrees. On Statement 6, there are 10 students (21.7\%) who strongly agree that they can use a smartphone or gadget to operate Microsoft Office 365 applications on learning History Subject, while there are 36 students $(78.3 \%)$ who agree with the statement. On Statement 7, there are 8 students (17.4\%) who strongly agree that they did not experience any difficulties and obstacles in using Microsoft Office 365 applications in the process of learning history during the Covid-19 pandemic. There are 26 students (56.5\%) who agree and 12 students $(26.1 \%)$ who disagree with the statement.

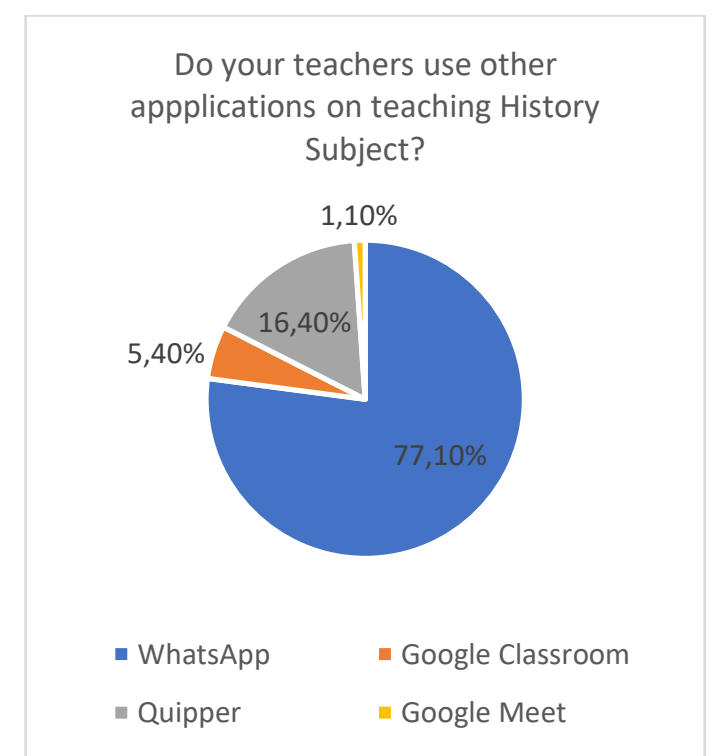

Fig. 3. Other Application used by the Teachers on Teaching History

Based on the figure above, the teachers also use other applications besides using Microsoft Office 365 on teaching History subjects. The figure shows that instead of using Microsoft Office 365, they use WhatsApp (77.1\%), Quipper (16.4\%), Google Classroom (5.4\%), and Google Meet (1.1\%). Based on the result of the interview, the students said that WhatsApp was used to chat with their teachers and friends about the history material (Cetinkaya, 2017); (Barhoumi, 2020). Besides, the teacher always gives instructions to the students using WhatsApp. It can be accessed by handphone or laptop and is easy to use (Singh, 2018). While Google Classroom was used in class X. Now, the school recommends the teachers used Microsoft Office 365. Google Classroom could be used to send the materials, and collect the students' assignments (Fauzan \& Arifin, 2019); and (Alim, Linda, Gunawan, \& Saad, 2019). 


\section{The Most Efficient Application Used for \\ Online Learning during the Covid-19 \\ Pandemic}

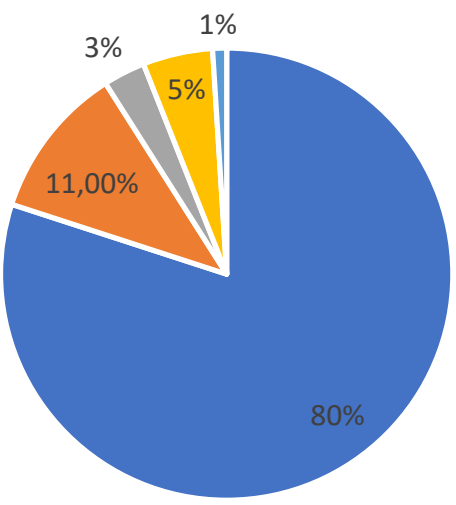

$$
\begin{aligned}
& \text { - Microsoft office } 365 \text { - WhatsApp } \\
& \text { - Google Classroom - Quipper } \\
& \text { - Google Meet }
\end{aligned}
$$

Fig. 4. The Most Efficient Application Used for Online Learning during the Covid-19 Pandemic

Based on the figure above, there are $80 \%$ of students think that Microsoft Office 365 is the most efficient application for online learning, especially on History Subject. The same result is in (Aziizah et al., 2020). It showed that the use of Microsoft Office 365 in learning history was quite effective and efficient. There are $11 \%$ of students who think that WhatsApp is the most efficient application for online learning, especially on History subjects. This result also is in line with (Susilawati \& Supriyatno, 2020) confirmed that WhatsApp could increase the students' outcomes in learning history. If the students use this application in a good way, it will help them to learn during online learning. Besides, according to Qamar, Riyadi, \& Wulandari (2019), WhatsApp can be also used in blended learning. In online learning, it can be used as a discussion forum to interact with the students. There are $3 \%$ of students who think that Google Classroom is the most efficient application for online learning especially on History subjects (Fitriningtiyas, Umamah, \& Sumardi, 2019). There are 5\% of students who think that Quipper is the most efficient application for online learning, especially on History subjects. There is only $1 \%$ of students think that Google Meet is the most efficient application for online learning, especially on History Subject. It's happened because the teachers recommend the students to use Microsoft Teams.

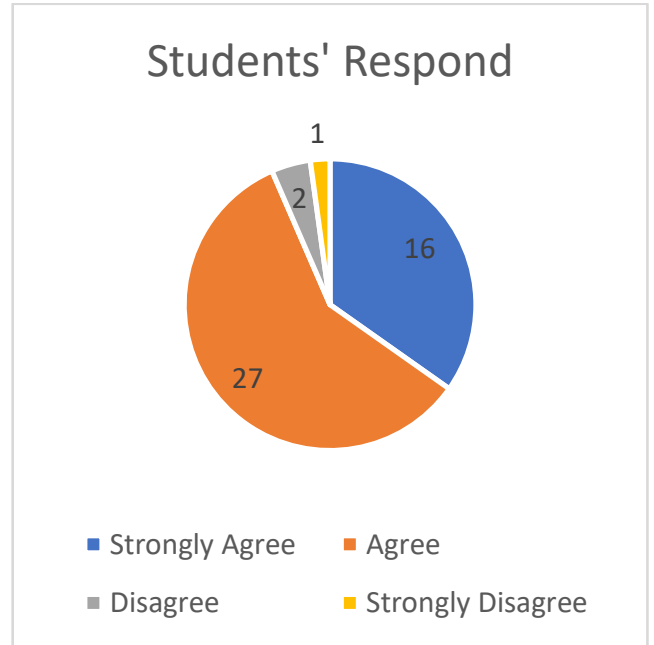

Fig. 5. Summary of Students' Perceptions

Based on Figure 5, there are 16 students (34.8\%) who strongly agree that all applications used by teachers are efficient for online learning especially on learning History subjects. Then, there are 27 students $(58.7 \%)$ who agree, 2 students $(4.3 \%)$ who disagree, and 1 student $(2.2 \%)$ who strongly disagrees that all applications used by teachers are efficient for online learning especially on learning History subjects.

\section{CONCLUSION}

There are some students' perceptions about the Microsoft Office 365 in History Subject, namely: first, this application has complete features with various uses, such as Microsoft Word, PowerPoint, Microsoft Teams. Making it is easier for students to access online learning. Second, this application can improve students' ability and interest in learning history. The display of this application is very clear and clear. Third, this application makes it easier for students to send assignments, presentations, and receive materials. However, the disadvantages of Microsoft Office 365 are network problems and data plans owned by students. This problem often arises in online learning.

\section{REFERENCES}

Alim, N., Linda, W., Gunawan, F., \& Saad, M. S. M. (2019). The effectiveness of Google Classroom as an instructional media: A case of state islamic institute of Kendari, Indonesia. Humanities and Social Sciences Reviews, 7(2), 240-246. https://doi.org/10.18510/hssr.2019.7227

Ardian, S. dkk. (2020). Pemanfaatan Microsoft Sway Dan Microsoft Form. 3(2), 66-74. Retrieved from http://jurnal.unsil.ac.id/index.php/bihari/article/view/2 $520 / 1543$

Aziizah, A., Sakti, T. B., \& Andriyanto, A. (2020). Pengaruh Pembelajaran Daring Mata Pelajaran Sejarah Melalui Microsoft Office 365. Keraton: Journal of History Education and Culture, 2(2), 104-119. 
https://doi.org/10.32585/.v2i2.1158

Barhoumi, C. (2020). The Effectiveness of WhatsApp Mobile Learning Activities Guided by Activty Theory on Students' Knowldege Management. Contemporary Educational Technology, 6(3), 221-238. https://doi.org/10.30935/cedtech/6151

Cetinkaya, L. (2017). The impact of WhatsApp use on success in education process. International Review of Research in Open and Distance Learning, 18(7), 5974. https://doi.org/10.19173/irrodl.v18i7.3279

Chang, C., \& Aytenew, G. (2021). Facing Challenges of Covid-19: The Perspective of China and Ethiopia Educational Institutions. JETL (Journal of Education, Teaching and Learning), 6(1), 62. https://doi.org/10.26737/jetl.v6i1.2288

Efriana, L. (2021). Problems of Online Learning during Covid-19 Pandemic in EFL Classroom and the Solution. JELITA:Journal of English Language Teaching and Literature, 2(1), 38-47.

Fauzan, F., \& Arifin, F. (2019). The Effectiveness of Google Classroom Media on the Students' Learning Outcomes of Madrasah Ibtidaiyah Teacher Education Department. Al Ibtida: Jurnal Pendidikan Guru MI, 6(2), 271. https://doi.org/10.24235/al.ibtida.snj.v6i2.5149

Fitriningtiyas, D. A., Umamah, N., \& Sumardi. (2019). Google classroom: As a media of learning history. IOP Conference Series: Earth and Environmental Science, 243(1). $1315 / 243 / 1 / 012156$

Nafisah, N. A., \& Fitrayati, D. (2021). Efektivitas Penerapan Aplikasi Microsoft Teams terhadap Hasil Pembelajaran Ekonomi Siswa SMA. Edukatif: Jurnal Ilmu Pendidikan, 3(5), 2761-2770.

Qamar, K., Riyadi, S., \& Wulandari, T. C. (2019). Utilization of WhatsApp application as discussion media in blended learning. Journal of Education and Learning (EduLearn), $13(3), \quad 370$. https://doi.org/10.11591/edulearn.v13i3.8412

Rijal Fadli, M., Sudrajat, A., Setiawan, R., \& Amboro, K. (2020). The Effectiveness of E-Module Learning History Inquiry Model to Grow Student Historical Thinking Skills Material Event Proclamation of Independence. International Journal of Advanced Science and Technology, 29(08), 1288-1295. Retrieved from https://www.researchgate.net/publication/342000497

Sanoto, H. (2021). Online Learning Management in the COVID-19 Pandemic Era. Journal of Education, Teaching, and Learning, 6(1), 47-52.

Singh, A. (2018). Facebook, WhatsApp , and Twitter: Journey towards Education. SOSHUM: Jurnal Sosial Dan Humaniora, $\quad 8(2), \quad 139-149$. https://doi.org/10.31940/soshum.v8i2.987

Situmorang, A. S. (2020). Microsoft Teams for Education Sebagai Media Pembelajaran. Microsoft Teams for Education Sebagai Media Pembelajaran Interaktif Meningkatkan Minat Belajar, 02(01), 30-35.
Susilawati, S., \& Supriyatno, T. (2020). Online Learning Through WhatsApp Group in Improving Learning Motivation in the Era and Post Pandemic COVID -19. Jurnal Pendidikan, 5(6), 852-859.

Umasih. (2018). History Subject in Indonesia During the New Order. Historia: Jurnal Pendidik Dan Peneliti Sejarah, 11(2), https://doi.org/10.17509/historia.v11i2.12332

Van Straaten, D., Wilschut, A., \& Oostdam, R. (2016). Making history relevant to students by connecting past, present and future: a framework for research. Journal of Curriculum Studies, 48(4), 479-502. https://doi.org/10.1080/00220272.2015.1089938

Widiyarso, T. H., \& Sutama. (2021). Efektifitas Penggunaan Microsoft Teams Dalam Pembelajaran E-Learning Bagi Guru Selama Pandemi Covid-19. Jurnal Pendidikan Dan Ilmu Pengetahuan, 21(1), 15-21.

Wirza, M. A., \& Ofionto. (2021). Penggunaan Microsoft Teams dalam Pembelajaran Daring pada Mata Pelajaran Sejarah di SMA Negeri 1 Bukittinggi. Journal Kronologi, 3(1), 106-118. 